\title{
The role of electronic health in the coronavirus disease crisis: A systematic review of documents
}

\author{
Parastoo Amiri' ${ }^{1}$, Kambiz Bahaadinbeigy ${ }^{2 *}$ (iD \\ ${ }^{1}$ Department of Health Information Sciences, Faculty of Management and Medical Informatics, Kerman University of Medical Sciences, Kerman, \\ Iran \\ ${ }^{2}$ Associate Professor, Department of Health Information Sciences, Faculty of Management and Medical Informatics, Kerman University of \\ Medical Sciences, Kerman, Iran
}

\begin{tabular}{|c|c|}
\hline Article Info & A B S T R A C T \\
\hline $\begin{array}{l}\text { Article type: } \\
\text { Review }\end{array}$ & \multirow{2}{*}{$\begin{array}{l}\text { Introduction: Epidemic diseases have always caused considerable physical } \\
\text { and financial casualties for governments. By the end of the year 2019, the } \\
\text { Covid19 pandemic emerged for the first time in China and rapidly infected } \\
\text { the globe. Objectives: As information technology plays a significant role in } \\
\text { the current healthcare system, the aim of the present study was to conduct } \\
\text { a systematic review to determine the role of electronic health in the Covid19 } \\
\text { crisis. }\end{array}$} \\
\hline $\begin{array}{l}\text { Article History: } \\
\text { Received: 2020-06-14 } \\
\text { Accepted: 2020-07-04 } \\
\text { Published: 2020-07-05 }\end{array}$ & \\
\hline $\begin{array}{l}\text { * Corresponding author: } \\
\text { Kambiz Bahadinbeigy } \\
\text { Associate Professor, Department of } \\
\text { Health Information Sciences, Faculty }\end{array}$ & $\begin{array}{l}\text { Material and Methods: This review was carried out on articles published } \\
\text { from December } 2019 \text { until March } 17 \text { th } 2020 \text { by searching keywords and } \\
\text { their equivalents in "MeSH" in PubMed, Web of Science, and Scopus } \\
\text { databases and Google search engine. }\end{array}$ \\
\hline $\begin{array}{l}\text { of Management and Medical } \\
\text { Informatics, Kerman University of } \\
\text { Medical Sciences, Kerman, Iran }\end{array}$ & $\begin{array}{l}\text { Results: In total, from } 72 \text { found articles, } 28 \text { were recognized based on their } \\
\text { research topic. After imposing inclusion and exclusion criteria, eventually } 6 \\
\text { original articles and } 8 \text { reports were selected for further analysis. Results } \\
\text { showed that reviewed articles had mentioned the effective role of IT in: } \\
\text { diagnosing Corona patients, addressing the spread of the disease, providing }\end{array}$ \\
\hline \multirow[t]{2}{*}{$\begin{array}{l}\text { Keywords: } \\
\text { Medical Informatics } \\
\text { Outbreaks } \\
\text { Covid-19 } \\
\text { Systematic Review }\end{array}$} & $\begin{array}{l}\text { high-risk areas. Telemedicine, machine learning algorithms, deep learning, } \\
\text { geogmented intelligence, neural networks, Global positioning system, and } \\
\text { technologies. }\end{array}$ \\
\hline & $\begin{array}{l}\text { Conclusion: It was shown that defeating the Covid } 19 \text { is impossible without } \\
\text { the help of technology. Experiences with the effectivity of using electronic } \\
\text { health in controlling and monitoring the prevalence of Covid } 19 \text { can be used } \\
\text { to deal with other pandemic diseases in the future as well; and to avoid } \\
\text { possible casualties and economic regressions while rapidly providing } \\
\text { solutions for similar critical situations. }\end{array}$ \\
\hline
\end{tabular}

Cite this paper as:

Amiri P, Bahaadinbeigy K. The Role of Electronic Health in the Coronavirus Disease Crisis: A Systematic Review of Documents. Front Health Inform. 2020; 9: 35. DOI: $10.30699 /$ fhi.v9i1.223

\section{INTRODUCTION}

The emergence and prevalence of pandemic viralinfectious diseases have been a major challenge in the twenty-first century. Over the recent years, the Ebola outbreak, the Middle East Respiratory Syndrome, SARS and avian influenza have caused significant health and economic damages to communities $[\underline{1}, \underline{2}]$. Based on a report presented by the World Health Organization (WHO), COVID-19 first emerged in Wuhan, China on December 30 2019 and rapidly infected a great number of its people over a short period [ $\underline{3}]$. On January $30^{\text {th }} 2020$, WHO had expressed its concern about the Corona disease being a public health emergency of international concern (PHEIC) [4], whose control would require a coordinated international response? This new unknown virus has been able to threaten the current advanced world despite its exceptional technologies. Two months after the Coronavirus outbreak (i.e. February 20 th 2020), China reported that 75465 individuals had been infected. Centers for disease control and prevention (CDC) reported that the incubation period of this unknown virus was approximately two weeks []. Since the Coronavirus is transmitted through the 
respiratory system, the virus has infected a majority of countries in less than a month. In order to prevent the prevalence of this virus, infected individuals with symptoms like coughing, shortness of breath, fever

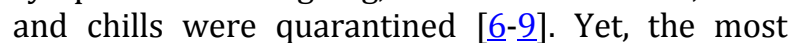
alarming transmitters of the disease were infected individuals with hidden symptoms, who were passing their incubation period, such as individuals with AIDS, tuberculosis and hepatitis B. The Ministry of Health of infected countries developed national curbing programs and urged all their people to selfquarantine and maintain social distancing to break the transmission chain of the virus. Providing remote health services to diagnose the disease and treat those infected is beneficial for governments when considering the rapid spread of this disease, the lack of a definitive treatment and the lack of sufficient quarantine infrastructures for infected patients.

IT has been widely used in the healthcare system for many years $[\underline{10}, \underline{11}]$ that it is impossible to imagine the system without it. The following studies reflect on the signifcant role of IT in different healthcare areas. In 2019, a reviw article stated that data gained from different technologies can contribute to the enrichment of healthcare databases, and also provide more accurate, effective, comprehensive and practical information about the pervalance of a disease, which can eventually contribute to better decision-making [12]. Also, having information about the distribution of patients, by use of the geographical information system (GIS), at an early stage of the pandemic is quite salient to provide early warnings and curb the outbreak as much as possible [13]. Until today, the use of artificial intelligent models has also been effective in the detection of many diseases [1422]. On the other hand, cell phones and web-based portals have also been successful in collecting health related data [23-28]. Given the effectiveness of technology-related approaches, such methods should be implemented in a timely manner to achieve faster results.

Numerous review studies are carried out on various subjects worldwide, especially in developed countries. As the Corona disease is relatively new, no review has been carried out on the subject ever since the outbreak of the disease. The results of such studies can be promising to programmers, system planners, and also care providers as it will help save time and improve the quality of provided services especially at times of disease outbreaks. The purpose of the present review was to investigate the role of electronic health during the outbreak of the Coronavirus disease.

\section{MATERIAL AND METHODS}

A systematic review was used to ensure the accuracy and comprehensivity of both the search and retrieval processes. To search for articles published on the concerned subject from 30/12/2019 to 17/03/2020, a combination of different keywords and their medical titles (MeSH) in English were used when searching PubMed, Web of Science and Scopus databases, as well as Google's search engine.

December $30^{\text {th }}, 2019$ was selected as the starting date for search because the Corona disease begun on this date. The search strategies are shown in Table 1. The inclusion criteria were as follows: the extracted articles had to be written in English, by human, be brief reports, case reports, letters to the editor, or prospects. Unrelated or repeated articles, or those written in a language other than English were excluded from the study. Among the articles, only those were selected in which the application of at least one IT software was mentioned.

Preferred reporting items for systematic reviews and meta-analyses (PRISMA) diagram was used to select articles (Fig 1). First, 72 articles were selected by use of the search strategies mentioned it Table 1. After adding those to Endnote software all articles were reviewed by two of the authors.

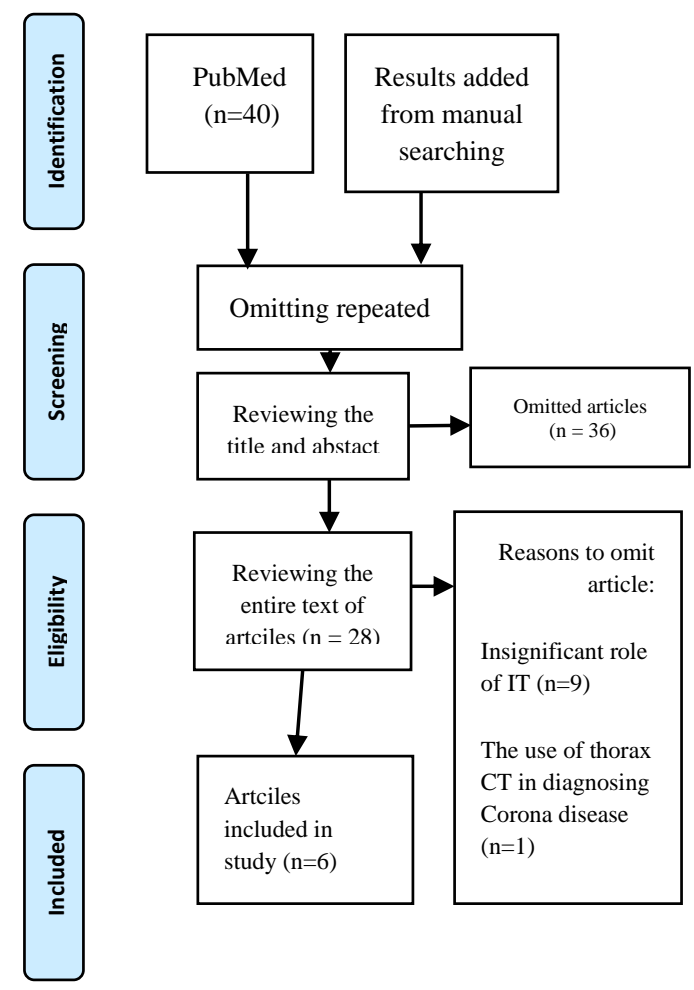

Fig 1: The process of article selection based on PRISMA 
Table 1: Search strategies in considered databases

\begin{tabular}{|c|c|}
\hline 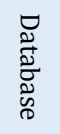 & Search strategy \\
\hline $\begin{array}{l}\tilde{J} \\
\tilde{E} \\
z \\
0 \\
0\end{array}$ & 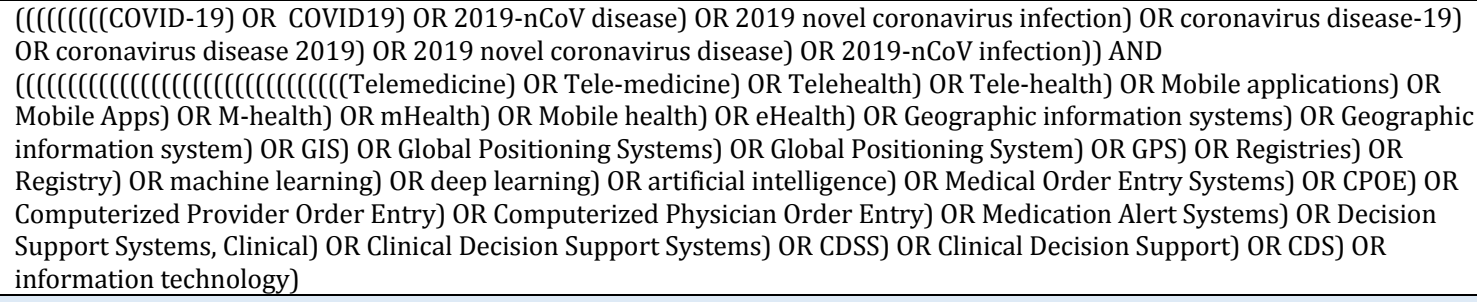 \\
\hline 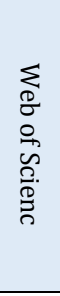 & $\begin{array}{l}\text { TS=(COVID-19 OR COVID19 OR (coronavirus disease 2019) OR (coronavirus disease-19) OR (2019 novel coronavirus } \\
\text { infection) OR (2019-nCoV disease) OR (2019 novel coronavirus disease) OR (2019-nCoV infection)) AND ((Telemedicine) OR } \\
\text { (Tele-medicine) OR (Telehealth) OR (Tele-health) OR (Mobile applications) OR (Mobile Apps) OR (M-health) OR (mHealth) } \\
\text { OR (Mobile health) OR (eHealth) OR (Geographic information systems) OR (Geographic information system) OR (GIS) OR } \\
\text { (Global Positioning Systems) OR (Global Positioning System) OR (GPS) OR (Registries) OR (Registry) OR (machine learning) } \\
\text { OR (deep learning) OR (artificial intelligence) OR (Medical Order Entry Systems) OR (CPOE) OR (Computerized Provider } \\
\text { Order Entry) OR (Computerized Physician Order Entry) OR (Medication Alert Systems) OR (Decision Support Systems, } \\
\text { Clinical) OR (Clinical Decision Support Systems) OR (CDSS) OR (Clinical Decision Support) OR (CDS) OR (information } \\
\text { technology)) }\end{array}$ \\
\hline & $\begin{array}{l}\text { 1: ((TITLE-ABS-KEY (covid-19) OR TITLE-ABS-KEY (covid19) OR TITLE-ABS-KEY (coronavirus AND disease 2019) OR } \\
\text { TITLE-ABS-KEY (coronavirus AND disease-19) OR TITLE-ABS-KEY (2019 novel AND coronavirus AND infection) OR TITLE- } \\
\text { ABS-KEY (2019-ncov AND disease) OR TITLE-ABS-KEY (2019 novel AND coronavirus AND disease) OR TITLE-ABS-KEY } \\
\text { (2019-ncov AND infection))) } \\
\text { 2: ((TITLE-ABS-KEY (telemedicine) OR TITLE-ABS-KEY (tele-medicine) OR TITLE-ABS-KEY (telehealth) OR TITLE-ABS-KEY } \\
\text { (tele-health) OR TITLE-ABS-KEY (mobile AND applications) OR TITLE-ABS-KEY (mobile AND apps) OR TITLE-ABS-KEY (m- } \\
\text { health) OR TITLE-ABS-KEY (mobile AND health) OR TITLE-ABS-KEY (mHealth) OR TITLE-ABS-KEY (eHealth) OR TITLE-ABS- } \\
\text { KEY (geographic AND information AND systems) OR TITLE-ABS-KEY (geographic AND information AND system) OR TITLE- } \\
\text { ABS-KEY (GIS) OR TITLE-ABS-KEY (global AND positioning AND systems ) OR TITLE-ABS-KEY (Global AND positioning AND } \\
\text { system) OR TITLE-ABS-KEY (GPS) OR TITLE-ABS-KEY (registries) OR TITLE-ABS-KEY (registry) OR TITLE-ABS-KEY } \\
\text { (machine AND learning) OR TITLE-ABS-KEY (deep AND learning) OR TITLE-ABS-KEY (artificial AND intelligence) OR TITLE- } \\
\text { ABS-KEY (medical AND order AND entry AND systems) OR TITLE-ABS-KEY (CPOE) OR TITLE-ABS-KEY } \\
\text { (computerized AND provider AND order AND entry) OR TITLE-ABS-KEY } \\
\text { (computerized AND physician AND order AND entry) OR TITLE-ABS-KEY (medication AND alert AND systems) OR TITLE- } \\
\text { ABS-KEY (decision AND support AND systems, AND clinical) OR TITLE-ABS-KEY } \\
\text { (clinical AND decision AND support AND systems) OR TITLE-ABS-KEY (CDSS) OR TITLE-ABS-KEY (CDS) OR TITLE-ABS-KEY } \\
\text { (clinical AND decision AND support) OR TITLE-ABS-KEY (information AND technology))) } \\
\text { \#1 AND \#2 }\end{array}$ \\
\hline
\end{tabular}

\section{RESULTS}

After holding several sessions with the two authors who analyzed the collected articles, and resolving contradictions, 6 original articles and 8 reports were included in the study. The descriptive presentation and study results were placed in two categories of original and other articles as shown in Tables 2 and 3 , respectively. As it has not been long after the emergence of the disease, the amount of existing data is limited.

Fong et al. [24] attempted to discover an accurate predictive model that could determine the prevalence of any epidemic disease with limited data by use of machine learning algorithms and artificial intelligence. They used group top-down prediction with a set of optimal prediction models with multiple input sources to predict. This procedure consists of 5 predictive models with complex machine learning models with multiple regression, the use of complex machine learning models, and the use of light machine learning models, simple data analysis and an econometric type of predicting temporal series.

Then, the different neural networks like combinatorial, combi-cf, Multilayer Iterative, and MIA-cf were compared by use of different inputs on how individuals had become infected (multivariate, corrective feedback, repetitive multilayered, and repetitive multilayer with corrective feedback) using different inputs on the stage of their disease (confirmed, treated, deceased, suspicious and critical). Eventually, by use of a self-structured method they succeeded to design a new predictive model called the polynomial neural network with corrective feedback (PNN+cf) which can be used for a limited small sample size at the time of any pandemic outbreak.

The Corona disease, just like SARS, emerged during spring in China [25]. Since the emergence of Corona was concurrent to China's spring season celebration, the number of those infected with Coronavirus began to rise; however, the disease had not yet turned into 
an epidemy and was not at its peak. After January $19^{\text {th }}$, the number of those suspected to be infected had significantly increased over a short period and the test of about $40-50 \%$ of these suspected cases turned out to be positive [13]. In order to prevent and control the spread of the disease the collaboration of all China's residents was required. Therefore, one of the salient measures used to prepare the public, especially in regions where the prevalence was low, was recognizing high-risk regions (areas where the number of infected individuals with Coronavirus was high). Relevant to this, Chen et al. [13] investigated the temporal and spatial distribution of Corona disease with use of GIS. Statistics showed that the number of mortalities in China from Corona Disease was $95.77 \%$ and $59.91 \%$ of which, were from Wuhan City in Hubei Province. Additionally, the highest rate of Corona disease pervalence and mortality was in Hubei; therefore, those who had travelled from Wuhan to other cities were the main causes of its outbreak there. Also, the very first cases reported to be infected in those cities where mainly from Wuhann.

For many, finding the strategies that defeat epidemics has always been a main concern. Duirng pandemics, the rapid increase in the number of infected individuals over a short period of time forces communities to respond rapidly. During the outbreak of epidemic diseases, IT and the media have played an important role in supporting communities and have greatly facilitated the monitoring and control of these diseases [26]. Information about Corona disease has been provided to the people in China via IT communicative channels (e.g. WeChat, mobile apps, etc.). Pan et al. [27] stated that China's reaction - as well as the world's reaction to the Coronavirus disease was faster than SARS. Some of these affective measures applied by the Chinese government was the use of a large data platform called "Close Contact Meter" on February $8^{\text {th }}$ to monitor and control Corona disease [28]. The platform worked in such way that by downloading and comparing national health data, those infected by Corona would be automatically detected. Also, companies like Alibaba and JD.com donated large amounts of medical equipment during the Corona disease outbreak. Scientific achievements, antibodies and antiviral drugs, also had an important role in fighting this epidemic and reducing mortalities.

The diagnosis of the Corona disease depends on different criteria like clinical symptoms, epidemiological history, CT scans, and positive pathological tests. The Nucleic Acid test is an invaluable test used for detecting the virus in the lower respiratory tract; however, the accuracy of this test in detecting the Coronavirus has been $30-50 \%$. Also, radiological scans are the main tools used in detecting the Corona disease as the CT scans of most infected patients showed similar features. It should be stated that for radiologists, diagnosing this disease has been much harder than diagnosing other viral pneumonias.

Wang et al. [299] searched for a solution to diagnose this disease by use of CT scans and deep learning algorithms. For this, they launched a website and uploaded CT scans accessible to healthcare providers and staff. The results of their study showed that their method was able to detect the virus with an accuracy rate of $83 \%$ which was significantly more precise than the Nucleic Acid test; and therefore, this method can help reduce the workload of physicians. Additionally, the developed artificial intelligence system used in the mentioned study can also help reduce the number of quarantined individuals and contribute to providing a timely treatment or controlling the Corona disease. On the other hand, the spread of the current disease and the possibility of the emergence of other Coronas in the future, has motivated governments to develop new treatments and rapid intervention protocols as quickly as possible.

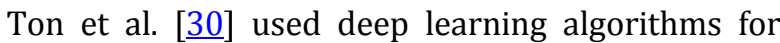
large-scale virtual screening to discover a new effective drug to treat the Corona disease. Currently, a few research groups have suggested potential suppression strategies and clinically approved drugs as a therapeutic solution for coronavirus [31-33]. In the above study, researchers used 1.3 billion compounds in the ZINC15 library to identify 1,000 potential ligands for the main protein of SARS-CoV-2. Eventually, the structure of the identified transplant compounds was made available to the public.

Today, Tele-Medicine has been recognized as a successful technology used in fighting pandemic diseases [34]. Zhai et al. [35] showed how TeleMedicine helped the Chinese government in fighting the Corona disease. The Chinese government designed a remote medical counseling app that could be installed on Chinese mobile phones, and established Huawei technologies to monitor and control this disease, called the emergency telemedicine consultation system (ETCS). The results showed that the 654 patients suffering from Corona disease had received counselings from this app, and 420 of these individuals were discharged from the hospital after 20 days.

Another advantage of this consulting center was that direct physical contanct among physicians, nurses and patients was avoided and thus the risk of them becoming infected was reduced. Since the specialized treatment team was not easily accessible everywhere, this center kept connected with patients by use of technologies like video conferencing. 
Table 2: Descriptive demonstration of the results of reviewed articles

\begin{tabular}{|c|c|c|c|c|c|c|c|}
\hline 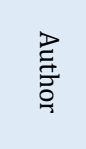 & ఏ & 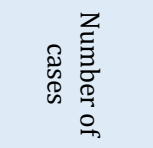 & 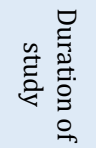 & 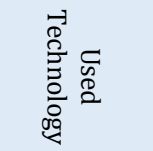 & $\stackrel{\rightleftarrows}{\exists}$ & 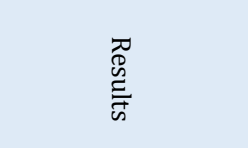 & 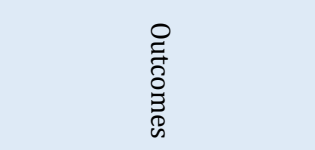 \\
\hline $\begin{array}{l}\text { Fong } \\
{[\underline{24}]}\end{array}$ & China & 14 & 6 days & $\begin{array}{l}\text { Machine } \\
\text { learning, } \\
\text { neural } \\
\text { network }\end{array}$ & $\begin{array}{l}\text { Discovering an } \\
\text { accurate predictive } \\
\text { model based on } \\
\text { small information } \\
\text { banks }\end{array}$ & $\begin{array}{l}\text { Obtaining a new } \\
\text { predictive model } \\
\text { named PNN+cf }\end{array}$ & $\begin{array}{l}\text { Using PNN + cf predictive } \\
\text { model in critical times of } \\
\text { the spread of any } \\
\text { epidemic disease when } \\
\text { the number of samples is } \\
\text { limited }\end{array}$ \\
\hline $\begin{array}{l}\text { Chen } \\
{[\underline{13}]}\end{array}$ & China & $\begin{array}{l}34 \text { in the } \\
\text { Province } \\
17 \text { in } \\
\text { Hubaei } \\
\text { City of } \\
\text { China }\end{array}$ & $\begin{array}{l}11 \\
\text { dasy }\end{array}$ & GIS & $\begin{array}{l}\text { Investigating the } \\
\text { temporal and } \\
\text { spatial spread of } \\
\text { the corona epidemy } \\
\text { to discover active } \\
\text { changes }\end{array}$ & $\begin{array}{l}\text { The number of } \\
\text { deaths in Wuhan } \\
\text { due to Corona was } \\
59.91 \% \\
\text { The number of } \\
\text { deaths in China due } \\
\text { to Corona was } \\
95.77 \%\end{array}$ & $\begin{array}{l}\text { Immigrants from Whuan } \\
\text { were the main causes of } \\
\text { the spread of the disease } \\
\text { in other cities } \\
\text { Understanding the } \\
\text { pattern of prevalence of } \\
\text { the disease and its risks in } \\
\text { different areas of China, } \\
\text { by the government and } \\
\text { people considering that } \\
\text { spring season celebration } \\
\text { was close }\end{array}$ \\
\hline $\begin{array}{l}\text { Pan } \\
{[\underline{27}]}\end{array}$ & China & $\begin{array}{l}\text { Consulting } \\
\text { with } \\
\text { general } \\
\text { health } \\
\text { specialists, } \\
\text { the } \\
\text { governmen } \\
\text { t and } \\
\text { people }\end{array}$ & $\mathrm{N} / \mathrm{A}$ & $\begin{array}{l}\text { Big data, } \\
\text { deep } \\
\text { sequencing } \\
\text {, electronic } \\
\text { business }\end{array}$ & $\begin{array}{l}\text { What do we learn } \\
\text { from China and the } \\
\text { global society in } \\
\text { dealing with the } \\
\text { spread of this } \\
\text { pandemic disease } \\
\text { when comparing } \\
\text { Corona with SARS? }\end{array}$ & $\begin{array}{l}\text { China and the } \\
\text { globe's reaction in } \\
\text { handling Corona } \\
\text { was much faster } \\
\text { than their reaction } \\
\text { towards SARS }\end{array}$ & $\begin{array}{l}\text { This response consists of: } \\
\text { Diagnosing the disease } \\
\text { Separating infected } \\
\text { patients } \\
\text { Providing financial } \\
\text { support } \\
\text { Building temoroary } \\
\text { hospitals } \\
\text { Applying traffic curbs }\end{array}$ \\
\hline $\begin{array}{l}\text { Wang } \\
\text { [무] }\end{array}$ & China & 99 patients & $\mathrm{N} / \mathrm{A}$ & $\begin{array}{l}\text { Deep } \\
\text { learning }\end{array}$ & $\begin{array}{l}\text { Deep learning } \\
\text { algorithm using CT } \\
\text { scans to screen } \\
\text { corona disease }\end{array}$ & $\begin{array}{l}\text { Domestic credit } \\
\text { was gained with } \\
82.9 \% \text { accuracy } \\
\text { and } 80.5 \% \\
\text { specificity and } 84 \% \\
\text { sensitivity; while } \\
\text { external } \\
\text { experimental data } \\
\text { sets showed } 73.1 \% \\
\text { accuracy and } 67 \% \\
\text { specificity and } 74 \% \\
\text { sensitivity. }\end{array}$ & $\begin{array}{l}\text { Using deep learning } \\
\text { method to extract } \\
\text { radiological features of } \\
\text { Corona patients' CT scans } \\
\text { is highly valuable }\end{array}$ \\
\hline $\begin{array}{l}\text { Zhai } \\
{[\underline{35}]}\end{array}$ & China & 654 & 20 & $\begin{array}{l}\text { Tele- } \\
\text { medicine }\end{array}$ & $\begin{array}{l}\text { How tele-medicine } \\
\text { can help in } \\
\text { defeating Corona } \\
\text { disease? }\end{array}$ & $\begin{array}{l}\text { Designing an } \\
\text { emergency remote } \\
\text { consulting system } \\
\text { in } 126 \text { hospitals }\end{array}$ & $\begin{array}{l}\text { Remote diagnosing and } \\
\text { consulting } \\
\text { Remote supervision of } \\
\text { patients } \\
\text { Remote multidisciplinary } \\
\text { caring } \\
\text { Remote educating } \\
\text { regarding disease } \\
\text { prevention }\end{array}$ \\
\hline $\begin{array}{l}\text { Ton } \\
{[\underline{30]}}\end{array}$ & Canada & $\mathrm{N} / \mathrm{A}$ & $\mathrm{N} / \mathrm{A}$ & $\begin{array}{l}\text { Deep } \\
\text { learning }\end{array}$ & $\begin{array}{l}\text { To discover new } \\
\text { drugs to treat } \\
\text { Corona } \\
\text { By use of deep } \\
\text { learning algorithms } \\
\text { for large-scale } \\
\text { virtual screening }\end{array}$ & $\begin{array}{l}\text { The possibilty of } \\
\text { rapidly estimating } \\
\text { the protein } \\
\text { structure of } 1.3 \\
\text { billion chemical } \\
\text { elements for } \\
\text { SARS-CoV-2 Mpro } \\
\text { active site }\end{array}$ & $\begin{array}{l}\text { Making recognized ligand } \\
\text { structures accessible to } \\
\text { the public }\end{array}$ \\
\hline
\end{tabular}


Table 3: Demonstrating the results of other studies

\begin{tabular}{|c|c|c|c|c|}
\hline$\underset{⿱}{\stackrel{D}{\Xi}}$ & $\frac{\substack{0 \\
0}}{\stackrel{3}{0}}$ & 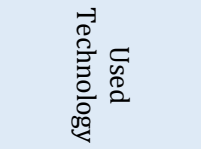 & $\stackrel{\mathbb{B}}{\mathrm{B}}$ & 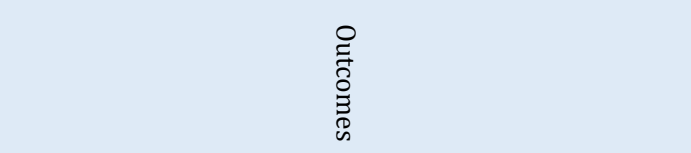 \\
\hline Rao [흐] & $\begin{array}{l}\text { A narrative } \\
\text { review in } \\
\text { form of a } \\
\text { letter to the } \\
\text { editor }\end{array}$ & $\begin{array}{l}\text { Artificial } \\
\text { intelligence, } \\
\text { machine } \\
\text { learning }\end{array}$ & $\begin{array}{l}\text { Using machine } \\
\text { learning algorithms } \\
\text { to identify people } \\
\text { with corona with the } \\
\text { help of mobile polls } \\
\end{array}$ & $\begin{array}{l}\text { Being economical } \\
\text { Helping the rapid identification and control of corona } \\
\text { patients } \\
\text { Faster identification of people with few disease } \\
\text { symptoms }\end{array}$ \\
\hline Tárnok [37] & $\begin{array}{l}\text { A narrative } \\
\text { review in } \\
\text { form of a } \\
\text { letter to the } \\
\text { editor }\end{array}$ & $\begin{array}{l}\text { Machine } \\
\text { learning }\end{array}$ & $\begin{array}{l}\text { Use of IT to reduce } \\
\text { travelings during the } \\
\text { Coronavirus outbreak }\end{array}$ & $\begin{array}{l}\text { Reduce travels } \\
\text { Reduce the risk of disease spread } \\
\text { Reduce expenses } \\
\text { Reduce air pollution caused by traveling } \\
\text { Reduce the insomnia and discomfort caused by air } \\
\text { traveling }\end{array}$ \\
\hline Boulos [40] & $\begin{array}{l}\text { A narrative } \\
\text { review in } \\
\text { form of a } \\
\text { letter to the } \\
\text { editor }\end{array}$ & GIS & $\begin{array}{l}\text { Introducing a variety } \\
\text { of geographic } \\
\text { trackers and } \\
\text { mappings of the } \\
\text { Corona disease, } \\
\text { The disease turning } \\
\text { into an epidemic and } \\
\text { its related events } \\
\text { around the world: GIS } \\
\text { technology in fighting } \\
\text { Corona }\end{array}$ & $\begin{array}{l}\text { Introducing Johns Hopkins University-centric dashboard } \\
\text { Introducing the World Health Organization dashboard } \\
\text { Introducing HealthMap to display geographic updates } \\
\text { and disease progression } \\
\text { Introducing the "close contact detector" program in China } \\
\text { Introducing the WorldPop program and analyzing the } \\
\text { amount of risk by determining the movement of people } \\
\text { from Wuhan to their destination } \\
\text { Introducing a map of incorrect information about Corona } \\
\text { around the globe on Twitter } \\
\text { Applying GIS technology in data sharing and providing } \\
\text { timely information in critical situations } \\
\text { Placing the informative dashboard about the spread of } \\
\text { the disease in the center } \\
\text { Monitoring the entire disease process by GIS }\end{array}$ \\
\hline Long [42] & $\begin{array}{l}\text { A narrative } \\
\text { review in } \\
\text { form of a } \\
\text { letter to the } \\
\text { editor }\end{array}$ & $\begin{array}{l}\text { virtual } \\
\text { Intelligence }\end{array}$ & $\begin{array}{l}\text { The role of enhanced } \\
\text { intelligence in } \\
\text { diagnosing and } \\
\text { preventing the } \\
\text { spread of Corona }\end{array}$ & $\begin{array}{l}\text { Rapid detection of epidemiological risks which allows the } \\
\text { prediction, prevention and recognition of future global } \\
\text { health risks }\end{array}$ \\
\hline Allam [ㄴ1] & $\begin{array}{l}\text { A narrative } \\
\text { review in } \\
\text { form of a } \\
\text { prespective }\end{array}$ & $\begin{array}{l}\text { Artificial } \\
\text { intelligence }\end{array}$ & $\begin{array}{l}\text { Proposing a smart } \\
\text { urban network by } \\
\text { creating standardized } \\
\text { protocols to increase } \\
\text { data sharing in the } \\
\text { event of a disease } \\
\text { outbreak or natural } \\
\text { calamity to monitor } \\
\text { and manage urban } \\
\text { health }\end{array}$ & $\begin{array}{l}\text { Preventing economic recession } \\
\text { Increasing urban safety } \\
\text { Standardizing data sharing } \\
\text { Increasing cooperation in times of crisis }\end{array}$ \\
\hline $\begin{array}{l}\text { Hollander } \\
{[\underline{38}]}\end{array}$ & $\begin{array}{l}\text { Narrative } \\
\text { review in } \\
\text { form of a } \\
\text { prespective }\end{array}$ & Tele-medicine & $\begin{array}{l}\text { Using tele-medicine } \\
\text { as an effective } \\
\text { method for treating } \\
\text { Corona patients }\end{array}$ & $\begin{array}{l}\text { Using web conferencing between physicians and patients } \\
\text { in emergencies } \\
\text { Using tablets by quarantined patients to control infection } \\
\text { Using Electronic intensive care unit (e-ICU) monitoring } \\
\text { programs by physicians } \\
\text { Using mobile-based healthcare programs }\end{array}$ \\
\hline $\begin{array}{l}\text { South } \\
\text { Korean } \\
\text { Epidemilogy } \\
\text { and case } \\
\text { management } \\
\text { team [우] }\end{array}$ & Breif report & $\begin{array}{l}\text { Global tracking } \\
\text { system }\end{array}$ & $\begin{array}{l}\text { A general review of } \\
\text { Corona patients and } \\
\text { clarifying the } \\
\text { different ways that } \\
\text { they had become in } \\
\text { contact with the } \\
\text { disease }\end{array}$ & $\begin{array}{l}\text { Providing accurate information about the location and } \\
\text { time of individual's exposure to the disease, and details } \\
\text { about their current condition }\end{array}$ \\
\hline $\operatorname{Li}[43]$ & Case report & Deep learning & $\begin{array}{l}\text { Investigating } \\
\text { laboratory results of } \\
\text { Real-time reverse- } \\
\text { transcriptase } \\
\text { polymerase chain } \\
\text { reaction (rRT-PCR) } \\
\text { based on deep } \\
\text { learning of two } \\
\text { Corona patients } \\
\end{array}$ & $\begin{array}{l}\text { Demonstrating a classification of the damages done to the } \\
\text { lungs and calculating the abnormalities by percentage } \\
\text { Determining the ratio of minor abnormalities found in the } \\
\text { lung to the entire lung, right upper lobe, right middle } \\
\text { lobe, right lower lobe, left upper lobe and left lower lobe }\end{array}$ \\
\hline
\end{tabular}


Letters to editors, prospects, or reports were also found in addition to the abovementioned articles, which had mentioned the effectivity and contribution of technology in diagnosing and reducing the spread of the Corona disease (Table 3). Rao [흐] emphasized the use of mobile programs that are based on machine learning algorithms in detecting patients with Corona disease.

Tárnok [37] has mentioned the use of teleconferencing technology and its benefits in dealing with Corona disease. Hollander et al. [요 described telemedicine as an excellent way to diagnose and treat Corona patients. In a report presented by the South Korean Epidemilogy and Case Management team [울 and Boulos [40] Global Tracking System and GIS have been recognized to be effective in tracking Corona patients.

In fact, Boulos mentioned the use of various geographical trackers in monitoring the Corona disease and finally introduces GIS as the most efficieint tool in dealing with pandemic diseases. Allam et al. [41] elaborated on the necessity to design intelligence city networks by use of artificial intelligence, during a pandemy or natural calamity, to better monitor and manage the health of the city and increase the accessibility to data. In another report presented by Long etl.al [ $\underline{42}$ ] it was stated that virtual intelligence can be used to diagnose and prevent the spread of the Corona disease, contributing to a rapid recognition of the global pandemic health risks in the future and defeat the disease. In a case report carried out on laboratory results by $\mathrm{Li}$ et al. [43], the significance of using deep learning algorithems in reading the CT scans of Corona patients was emphasized as such that by use of these algorithms it was possible to demonstrate, in percentages, the damages caused by Corona disease and the amount of harm caused to the lungs.

\section{DISCUSSION}

Pandemic diseases like SARS, MERS, and H1N1, should be prioritized over non-contagious disease. Each of these diseases has left drastic social and economic effects on different countries of the globe, as such that America tolerated 30 billion dollars economic loss in year 2003 due to SARS [44]. Additionally, there were many mortalities and the normal living conditions were disrupted in infected countries [1, 2]. Having insufficient information about epidemic diseases and their way of transmission in the past has led to countless deaths including the Black Death pandemic from the plague pneumonia (caused 30-60\% deaths in Europe) in the fourteenth century [45], the Influenza pandemic in the early twentieth century which caused about 50 million deaths [46, 47], Malaria which killed one person every 60 seconds [48], and AIDS which caused about 32 million deaths by the end of 2018 [49]. These events show that a new pandemic disease can spread quite rapidly and to overcome them using the help of other disciplines to research and inform the public is essential. In this study, those articles were reviewed which had investigated the effects of using different technologies in the spread of the Corona disease. Although this issue has been the focus of few studies, the results of this review showed that the use of different technologies has been effective during the spread of the Corona disease.

As the results showed, the range of the technological aims investigated in the reviewed articles were diagnosing the Corona disease and reducing its spread. Most studies had stated that machine learning algorithms and artificial intelligence methods could be used to diagnose the disease. These results indicate that scholars are well aware of the potential and usefulness of these algorithms and conducting research on intellectual systems. For example, the results of this review showed that in 2018, machine learning algorithms and artificial intelligence can be promising in helping patients in different areas of healthcare [ [0] ], such as the use of machine learning algorithms and artificial intelligence in treating viral epidemic diseases like

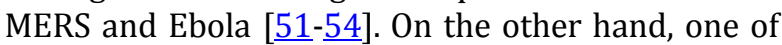
the most salient challenges for smart systems is the problem of knowledge acquisition; for instance, in designing a Neural Network the number of samples required to educate the system is one of the main issues. Fong et al. investigated this and succeeded to find a promising method to address this issue [24].

On the other hand, most of the reviewed articles had stated that GIS and global tracking systems were effective tools in discovering infected individuals and their connections with other environmental data. Perhaps nothing is more effective in controlling the prevalence of pandemic diseases than monitoring the geographical distribution of these diseases [ㄷ5]. In a study conducted by Gleason et al. [ㄷ] on the Ebola virus in 2014, it was shown that GIS techniques are effective mechanisms in investigating related temporal and spatial risk factors of pandemic diseases in the future. In 2019, Al-Ahamd et al. [7] conducted a study in Saudi Arabia on the effective use of important temporal and spatial factors that had led to the emergence of MERS in that country, by use of the GIS. Analyzing these connections with the help of such software can help reduce undesirable effects caused by encountering infected patients and also improve the healthcare of others who have been exposed to the virus and have become vulnerable. Yet, since the GIS software is not able to perform statistically complicated calculations, many scholars believe that these software, are not suitable tools for conducting epidemiological studies [ㅌ]. Still, however, the potential of GIS in connecting patients to geographical and spatial data is unquestionable, 
and it has made invaluable contributions to healthcare systems at the time of the pandemic diseases spread.

Over the last decade, the demand for telemedicine services in developed countries has increased [ $[\underline{59}$, 60]. Zhai et al. [하] was a successful study on the use of telemedicine in defeating the prevalence of Corona disease. It is noteworthy that China has also successfully used telemedicine services in an earthquake that occurred in 2013 [61]. They set up specialized remote medical assisting teams in the hospitals at the site of the earthquake to have remote consult with other specialists at other hospitals. Many patients were treated thanks to this remote system. The results of studies have shown that for many reasons, in many cases, telemedicine has been equivalent to or better than face-to-face methods.

Zhai and Tárnok [37] each have mentioned these causes in their studies, and Hollander has mentioned the different effective remote medical tools used in reducing face-to-face contacts between physicians and patients [요. Other benefits of telemedicine include day and night accessibility.

The limitations of Wang et al. [29] and Zhai et al. [35] studies were that they had not yet been evaluated by journals and since the number of published articles were limited, these studies were included in this review.

\section{CONCLUSION}

The novelty of the Coronavirus prevalence is one of

\section{REFERENCES}

1. Morens DM, Folkers GK, Fauci AS. The challenge of emerging and re-emerging infectious diseases. Nature. 2004; 430(6996): 242-9. PMID: 15241422 DOI: $10.1038 /$ nature02759 [PubMed]

2. Suwantarat N, Apisarnthanarak A. Risks to healthcare workers with emerging diseases: lessons from MERSCoV, Ebola, SARS, and avian flu. Curr Opin Infect Dis. 2015; 28(4): 349-61. PMID: 26098498 DOI: 10.1097/QC0.0000000000000183 [PubMed]

3. Paraskevis D, Kostaki EG, Magiorkinis G, Panayiotakopoulos G, Sourvinos G, Tsiodras S. Fullgenome evolutionary analysis of the novel corona virus (2019-nCoV) rejects the hypothesis of emergence as a result of a recent recombination event. Infect Genet Evol. 2020; 79: 104212. PMID: 32004758 DOI: $10.1016 /$ j.meegid.2020.104212 [PubMed]

4. World Health Organization. Statement on the second meeting of the international health regulations (2005) emergency committee regarding the outbreak of novel coronavirus (2019-nCoV). Geneva, Switzerland. 2020 . the main reasons that limited articles were available on the subject. Technology and health information systems are now intertwined and rapidly expanding since it is expected that they play a prominent role during the outbreak of the Corona disease. The results of this study showed that it would be impossible to control Corona disease without the help of technology. Since health system managers need to be aware of the measures taken with the help of technology during the outbreak of this disease in different societies, it is recommended that related institutions develop necessary measures to facilitate the conduct of different research in this area.

\section{ACKNOWLEDGEMENT}

This article was carried out with the support of [Blinded] University of Medical Sciences (Research code: IR.KMU.REC.1398.726).

\section{AUTHOR'S CONTRIBUTION}

The authors agree on this final form of the manuscript, and attested that all authors contributed in the final draft of the manuscript.

\section{CONFLICTS OF INTEREST}

The authors declare no conflicts of interest regarding the publication of this study.

\section{FINANCIAL DISCLOSURE}

No financial interests related to the material of this manuscript have been declared.

5. Centers for Disease control and Prevention. Prevent getting sick [Internet]. 2020 [cited: 1 Jun 2020; updated: 7 May 2020]. Available from: https://www.cdc.gov/coronavirus/2019ncov/prepare/index.html.

6. Wang D, Hu B, Hu C, Zhu F, Liu X, Zhang J, et al. Clinical characteristics of 138 hospitalized patients with 2019 novel coronavirus-infected pneumonia in Wuhan, China. JAMA. 2020; 323(11): 1061-9. PMID: 32031570 DOI: 10.1001/jama.2020.1585 [ubMed]

7. Chen N, Zhou M, Dong X, Qu J, Gong F, Han Y, et al. Epidemiological and clinical characteristics of 99 cases of 2019 novel coronavirus pneumonia in Wuhan, China: A descriptive study. The Lancet. 2020; 395(10223): 507-13.

8. Li Q, Guan X, Wu P, Wang X, Zhou L, Tong Y, et al. Early transmission dynamics in Wuhan, China, of novel coronavirus-infected pneumonia. N Engl J Med. 2020; 382(13): 1199-207. PMID: 31995857 DOI: 10.1056/NEJMoa2001316 [PubMed]

9. Huang C, Wang Y, Li X, Ren L, Zhao J, Hu Y, et al. Clinical features of patients infected with 2019 novel coronavirus in Wuhan, China. The Lancet. 2020; 395(10223): 497-506. 
10. Ammenwerth E, Brender J, Nykänen P, Prokosch H-U, Rigby M, Talmon J. Visions and strategies to improve evaluation of health information systems: Reflections and lessons based on the HIS-EVAL workshop in Innsbruck. Int J Med Inform. 2004; 73(6): 479-91. PMID: 15171977 DOI: 10.1016/j.ijmedinf.2004.04.004 [PubMed]

11. Kaplan B. Evaluating informatics applications-some alternative approaches: Theory, social interactionism, and call for methodological pluralism. Int J Med Inform. 2001; 64(1): 39-56. PMID: 11673101 DOI: 10.1016/s1386-5056(01)00184-8 [PubMed]

12. Boulos MNK, Peng G, VoPham T. An overview of GeoAI applications in health and healthcare. Int J Health Geogr. 2019; 18(1): 7. PMID: 31043176 DOI: 10.1186/s12942-019-0171-2 [PubMed]

13. Chen Z, Zhang Q, Lu Y, Guo Z, Zhang X, Zhang W, et al. Distribution of the COVID-19 epidemic and correlation with population emigration from Wuhan, China. Chin Med J (Engl). 2020; 133(9): 1044-50. PMID: $32118644 \quad$ DOI: 10.1097/CM9.0000000000000782 [ubMed]

14. Neill DB. Using artificial intelligence to improve hospital inpatient care. IEEE Intelligent Systems. 2013; 28(2): 92-5.

15. Rajalakshmi R, Subashini R, Anjana RM, Mohan V. Automated diabetic retinopathy detection in smartphone-based fundus photography using artificial intelligence. Eye. 2018; 32(6): 1138-44.

16. Arabasadi Z, Alizadehsani R, Roshanzamir M, Moosaei $\mathrm{H}$, Yarifard AA. Computer aided decision making for heart disease detection using hybrid neural networkGenetic algorithm. Computer Methods and Programs in Biomedicine. 2017; 141: 19-26.

17. Kumar VB, Kumar SS, Saboo V. Dermatological disease detection using image processing and machine learning. International Conference on Artificial Intelligence and Pattern Recognition; IEEE: 2016.

18. Tomlinson M, Solomon W, Singh Y, Doherty T, Chopra $\mathrm{M}$, Ijumba $\mathrm{P}$, et al. The use of mobile phones as a data collection tool: A report from a household survey in South Africa. BMC Med Inform Decis Mak. 2009; 9: 51. PMID: 20030813 DOI: 10.1186/1472-6947-9-51 [PubMed]

19. Azevedo JP, Ballivian A, Durbin W. Using mobile phones for high-frequency data collection. In Toninelli R, Pinter R, dePadraza P (eds). Mobile research Methods: Opmortunities and challenges of mobile research methodologies. London: Ubiquity Press; 2015.

20. Braun R, Catalani C, Wimbush J, Israelski D. Community health workers and mobile technology: A systematic review of the literature. PLoS One. 2013; 8(6): e65772. PMID: 23776544 DOI: 10.1371/journal.pone.0065772 [․ubMed]

21. Bastawrous A, Armstrong MJ. Mobile health use in low-and high-income countries: An overview of the peer-reviewed literature. J R Soc Med. 2013; 106(4): 130-42. PMID: 23564897 DOI:

\subsection{7/0141076812472620 [PubMed]}

22. Paolotti D, Carnahan A, Colizza V, Eames K, Edmunds J, Gomes G, et al. Web-based participatory surveillance of infectious diseases: The Influenzanet participatory surveillance experience. Clin Microbiol Infect. 2014; 20(1): 17-21. PMID: 24350723 DOI: 10.1111/14690691.12477 [PubMed]

23. Fabic MS, Choi Y, Bird S. A systematic review of demographic and health surveys: Data availability and utilization for research. Bull World Health Organ. 2012; 90(8): 604-12. PMID: 22893744 doi: 10.2471/BLT.11.095513 [PubMed]

24. Fong SJ, Li G, Dey N, Crespo RG, Herrera-Viedma E. Finding an accurate early forecasting model from small dataset: A case of 2019-nCoV novel coronavirus outbreak. International Journal of Interactive Multimedia \& Artificial Intelligence. 2020; 6(1): 13240.

25. Li W, Shi Z, Yu M, Ren W, Smith C, Epstein JH, et al. Bats are natural reservoirs of SARS-like coronaviruses. Science. 2005; 310(5748): 676-9. PMID: 16195424 DOI: $10.1126 /$ science.1118391 [PubMed]

26. Al-Surimi K, Khalifa M, Bahkali S, Ashraf E-M, Househ M. The potential of social media and internet-based data in preventing and fighting infectious diseases: From internet to twitter. Adv Exp Med Biol. 2017; 972: 131-9. PMID: 28004307 DOI: 10.1007/5584_2016_132 [PubMed]

27. Pan X, Ojcius DM, Gao T, Li Z, Pan C, Pan C. Lessons learned from the 2019-nCoV epidemic on prevention of future infectious diseases. Microbes and Infection. 2020; 22(2): 86-91.

28. Are you a close contact? Close contact meter is online [Internet]. 2020 [cited: 1 Jun 2020]. Available from: https://baijiahao.baidu.com/s?id=16579732490618 $79950 \& w f r=s p i d e r \&$ for $=p c$.

29. Wang S, Kang B, Ma J, Zeng X, Xiao M, Guo J, et al. A deep learning algorithm using CT images to screen for Corona Virus Disease (COVID-19). medRxiv. 2020.

30. Ton AT, Gentile F, Hsing M, Ban F, Cherkasov A. Rapid identification of potential inhibitors of SARS-CoV-2 main protease by deep docking of 1.3 billion compounds. Mol Inform. 2020; 10: 1002. PMID: 32162456 DOI: $10.1002 / \operatorname{minf} .202000028$ [PubMed]

31. Li Y, Zhang J, Wang N, Li H, Shi Y, Guo G, et al. Therapeutic drugs targeting 2019-nCoV main protease by high-throughput screening. bioRxiv. 2020.

32. Xu Z, Peng C, Shi Y, Zhu Z, Mu K, Wang X, et al. Nelfinavir was predicted to be a potential inhibitor of 2019-nCov main protease by an integrative approach combininghomology modelling, molecular docking and binding free energy calculation. bioRxiv. 2020.

33. Liu X, Wang X-J. Potential inhibitors for 2019-nCoV coronavirus $\mathrm{M}$ protease from clinically approved medicines. bioRxiv. 2020.

34. Williams AR, Bisaga A. From AIDS to opioids: How to combat an epidemic. N Engl J Med. 2016; 375(9): 8135. PMID: 27579632 DOI: 10.1056/NEJMp1604223 


\section{[PubMed]}

35. Zhai Y, Wang Y, Zhang M, Gittell JH, Jiang S, Chen B, et al. From isolation to coordination: How can telemedicine help combat the COVID-19 outbreak? medRxiv. 2020

36. Rao ASS, Vazquez JA. Identification of COVID-19 can be quicker through artificial intelligence framework using a mobile phone-based survey in the populations when cities/towns are under quarantine. Infect Control Hosp Epidemiol. 2020;1-5. PMID: 32122430 DOI: 10.1017/ice.2020.61 [PubMed]

37. Tárnok A. Machine learning, COVID-19 (2019-nCoV), and multi-OMICS. Cytometry A. 2020; 97(3): 215-6. PMID: 32142596 DOI: $10.1002 /$ cyto.a.23990 [PubMed]

38. Hollander JE, Carr BG. Virtually perfect? Telemedicine for Covid-19. N Engl J Med. 2020; 382(18): 1679-81. PMID: 32160451 DOI: $10.1056 /$ NEJMp2003539 [PubMed]

39. COVID-19 National Emergency Response Center, Epidemiology \& Case Management Team, Korea Centers for Disease Control \& Prevention. Contact transmission of COVID-19 in South Korea: Novel investigation techniques for tracing contacts. Osong Public Health Res Perspect. 2020; 11(1): 60-3. PMID: $32149043 \quad$ DOI: $\quad 10.24171 /$ j.phrp.2020.11.1.09 [PubMed]

40. Kamel Boulos MN, Geraghty EM. Geographical tracking and mapping of coronavirus disease COVID19/severe acute respiratory syndrome coronavirus 2 (SARS-CoV-2) epidemic and associated events around the world: how 21st century GIS technologies are supporting the global fight against outbreaks and epidemics. International Journal of Health Geographics. 2020; 19(1): 8.

41. Allam Z, Jones DS. On the Coronavirus (COVID-19) outbreak and the smart city network: Universal data sharing standards coupled with artificial intelligence (AI) to benefit urban health monitoring and management. Healthcare. 2020; 8(1): 46.

42. Long JB, Ehrenfeld JM. The role of augmented intelligence (AI) in detecting and preventing the spread of novel coronavirus. Journal of Medical Systems. 2020; 44(3): 59.

43. Li D, Wang D, Dong J, Wang N, Huang H, Xu H, et al. False-negative results of real-time reversetranscriptase polymerase chain reaction for severe acute respiratory syndrome coronavirus 2: Role of deep learning-based CT diagnosis and insights from two cases. Korean J Radiol. 2020; 21(4): 505-8. PMID: 32174053 DOI: 10.3348/kjr.2020.0146 [PubMed]

44. World Health Organization. Severe acute respiratory syndrome (SARS): Multi-country outbreak [Internet] 2003 [cited: 1 May 2020; updated: 11 Apr 2003]. Available https://www.who.int/csr/don/2003_04_11/en./

45. Alchon SA. A pest in the land: New world epidemics in a global perspective. UNM Press; 2003.

46. Taubenberger JK, Kash JC, Morens DM. The 1918 influenza pandemic: 100 years of questions answered and unanswered. Sci Transl Med. 2019; 11(502): eaau5485. PMID: 31341062 DOI: 10.1126/scitranslmed.aau5485 [PubMed]

47. Taubenberger JK, Reid AH, Krafft AE, Bijwaard KE, Fanning TG. Initial genetic characterization of the 1918 "Spanish" influenza virus. Science. 1997; 275(5307): 1793-6. PMID: 9065404 DOI: 10.1126/science.275.5307.1793 [PubMed]

48. Strydom K-A, Ismail F, Frean J. Plasmodium ovale: A case of not-so-benign tertian malaria. Malaria Journal. 2014; 13(1): 85.

49. UNAIDS. Global HIV \& AIDS statistics: 2020 fact sheet [Internet]. 2020 [cited: 15 May 2020]. Available from: https://www.unaids.org/en/resources/fact-sheet.

50. Murali N, Sivakumaran N. Artificial intelligence in healthcare: A review. International Journal of Modern Computation, Information and Communication Technology. 2018; 1(6): 103-10.

51. Abdullah M, Altheyab M, Lattas A, Algashmari W. MERS-CoV disease estimation (MDE): A study to estimate a MERS-CoV by classification algorithms. In deAlencar S (Ed). Communication, Management and Information Technology. London: CRC Press; 2016.

52. John M, Shaiba H. Main factors influencing recovery in MERS Co-V patients using machine learning. Journal of Infection and Public Health. 2019; 12(5): 700-4.

53. Ekins S, Freundlich JS ,Clark AM, Anantpadma M, Davey RA, Madrid P. Machine learning models identify molecules active against the Ebola virus in vitro. F1000Res. 2015; 4: 1091. PMID: 26834994 DOI: 10.12688/f1000research.7217.3 [PubMed]

54. Madrid PB, Chopra S, Manger ID, Gilfillan L, Keepers TR, Shurtleff AC, et al. A systematic screen of FDAapproved drugs for inhibitors of biological threat agents. PLoS One. 2013; 8(4): e60579. PMID: 23577127 DOI: 10.1371/journal.pone.0060579 [PubMed]

55. Meade MS. Medical geography. The Wiley Blackwell Encyclopedia of Health, Illness, Behavior, and Society. Wiley Open Library; 2014.

56. Gleason BL, Foster S, Wilt G, Miles B, Lewis B, Cauthen $\mathrm{K}$, et al. Geospatial analysis of household spread of Ebola virus in a quarantined village-Sierra Leone, 2014. Epidemiol Infect. 2017; 145(14): 2921-9. PMID: 28826426 DOI: $10.1017 /$ S0950268817001856 [PubMed]

57. Al-Ahmadi $\mathrm{K}$, Alahmadi S, Al-Zahrani A Spatiotemporal clustering of middle east respiratory syndrome coronavirus (MERS-CoV) incidence in Saudi Arabia, 2012-2019. Int J Environ Res Public Health. 2019; 16(14): 2520. PMID: 31311073 DOI: 10.3390/ijerph16142520 [PubMed]

58. Musa GJ, Chiang P-H, Sylk T, Bavley R, Keating W, Lakew B, et al. Use of GIS mapping as a public health tool: from cholera to cancer. Health Serv Insights. 2013; 6: 111-6. PMID: 25114567 DOI: 10.4137/HSI.S10471 [PubMed]

59. Anker SD, Koehler F, Abraham WT. Telemedicine and remote management of patients with heart failure. 
Lancet. 2011; 378(9792): 731-9. PMID: 21856487 DOI: 10.1016/S0140-6736(11)61229-4 [PubMed]

60. Yager P, Dapul H, Murphy S, Clark M, Zheng H, Noviski $\mathrm{N}$. Comparison of face-to-face versus telemedicine patient assessment in a pediatric intensive care unit. Critical Care Medicine. 2012; 40(12): 1-23.
61. Li T, Chai J. Implementation of telemedicine services in the earthquake disaster relief: The best medical experts provide direct medical service to the affected people. Zhonghua Wei Zhong Bing Ji Jiu Yi Xue. 2013; 25(5): 262-4. PMID: 23663571 DOI: 10.3760/cma.j.issn.2095-4352.2013.05.003 [PubMed] 